\title{
The Effects of Trade Openness on Economic Growth in Africa
}

\author{
Madinatou Yeh Bunje, Simon Abendin, Yin Wang* \\ School of Business, Zhengzhou University, Zhengzhou, China \\ Email: *zzuwangyin@163.com
}

How to cite this paper: Bunje, M. Y., Abendin, S., \& Wang, Y. (2022). The Effects of Trade Openness on Economic Growth in Africa. Open Journal of Business and Management, 10, 614-642. https://doi.org/10.4236/ojbm.2022.102035

Received: January 11, 2022

Accepted: February 28, 2022

Published: March 3, 2022

Copyright $\odot 2022$ by author(s) and Scientific Research Publishing Inc. This work is licensed under the Creative Commons Attribution International License (CC BY 4.0).

http://creativecommons.org/licenses/by/4.0/ (c) (i) Open Access

\begin{abstract}
This study aimed to enhance how trade openness is measured by including facets of nations' global trade integration to generate four distinct measures: exports plus imports to GDP ratio, the ratio of exports to GDP, the ratio of imports to GDP, and their combined effect index. We use the pooled ordinary least square, fixed effects, and the system generalized methods of moment's estimation approaches to analyze balanced panel data from 52 African nations from 2000 to 2018 . The results show an intriguing mixed pattern between trade openness and GDP per capita: 1) POLS show trade openness has a mixed influence on economic growth. Similarly, when subdividing Africa into sub-regions, trade openness demonstrated a non-linear relationship with GDP, but the result in Northern Africa is sturdy in terms of economic growth. 2) Trade openness has a negative and statistical effect on GDP per capita, as per the fixed-effects model. 3) Finally, the sys-GMM verifies that trade openness is not resilient across various openness measures and robustness regression estimates. In particular, the findings suggest that imports stifle growth while exports boost growth in Africa. In this context, we advocate that governments pursue the new structural economic policies to encourage export expansion and promote economic growth.
\end{abstract}

\section{Keywords}

Trade Openness, Pooled Ordinary Least Square, Fixed and Random Effects, System GMM, Africa

\section{Introduction}

When economic historians look back on the past century, they will undoubtedly be interested in the enigma of divergent performances among countries, particularly in the second half of the twentieth century. Nations like Brazil, Chile, 
China, Indonesia, India, Korea, Malaysia, Mauritius, Singapore, Thailand, and Vietnam have achieved tremendous openness-growth and lifted hundreds of millions of people out of poverty in a decade (Lin, 2011). These nations would be perplexed, however, by the seeming inability of African countries, where mankind has stayed imprisoned in poverty (UNCTAD, 2016). Despite the tremendous efforts made by developing countries and the help of many global development agencies, there was little economic convergence between rich and poor countries (Lin, 2011). Besides, policymakers of the developing countries wish to know the likely magnitudes of international trade over their relevant time horizons (Pritchett, 2006). These time horizons are typically short for policy advisors in emerging countries, as obtaining high growth rates is a key policy goal.

In contrast, much of the literature on endogenous growth focuses on long-term growth factors that span decades. As a result, it is vital to discern between policies that can be implemented efficiently in the short to medium term and those that will take decades to implement. The existing growth literature has largely ignored this issue since, Hicks (1965) points out, advances in growth theory have little relevance for developing economies. The Solow model, for instance, can be used to examine the short, medium, and long-run effects of international trade on economic growth. The policymakers of developing countries are interested in these short to medium-term transitory growth effects because increasing economic integration is a relatively simple policy option to implement compared to institutional reforms, which are difficult to implement and require a long time to be effective (Rao \& Cooray, 2012). This study also opposes the endogenous model policy study on African studies conducted by Le Goff and Singh (2014), Zahonogo (2016), Huchet-Bourdon et al. (2018), and Gabriel and David (2021). Emphasizing that the analysis of international trade has received a lot of attention in economic literature, but these equally essential concerns of time-horizon have received less attention. We implement the new structural economics in the quest for long-term growth plans since it complements prior techniques.

Lin and Monga (2010) developed the new structural economic framework based on an examination of the growth process in modern times and across continents. It begins with the insight that constantly technological innovation and structural change are the hallmarks of modern economic progress. To solve market failures that prevent countries from diversifying their products, the New Structuralist Economic (NSE) theory suggests that the state should act as an enabling agent through trade policy (UNIDO \& UNCTAD, 2011; Lin \& Monga, 2010). According to Lin (2012), it has taken the approach of "trying to ingest and digest the accumulated experience of growth and development, as well as rigorous and thoughtful policy analysis in a wide range of disciplines". It also provides a framework for understanding the endogeneity and exogeneity issues surrounding: taking advantage of the global economy through openness and maintaining macroeconomic stability.

According to Asiedu (2013) and Doan (2019), Africa among other developing 
countries remains a major barrier for emerging economies all over the world. As a result, researchers have conducted several empirical studies to determine the impact of international trade on economic development in Africa and the rest of the continents. On the one hand, several empirical research has found that foreign trade has a favorable impact on economic growth (Doan, 2019; Frankel \& Romer, 1999; Chang \& Mendy, 2012; Manwa \& Wijeweera, 2016; Zahonogo, 2016). On the other hand, some researchers claim that international trade has a negative or inconsistent impact on economic progress in Africa and the rest of the globe (Ramzan et al., 2019; Gabriel \& David, 2021; Manwa et al., 2019; Menyah et al., 2014; Ulaşan, 2012; Hye \& Lau, 2015). These inconsistent (inconclusive) findings persist, implying that further research is needed to close the knowledge gap by taking into consideration the adequate growth model for developing countries and more distinctively, the relevance of the new structural economic theory towards policy implication.

More specifically, the contributions of this study are: firstly, recognized that the 19-year accumulation of highly relevant (both successful and poor) growth experiences provides a unique source of learning. To the best of our knowledge, there had been no longitudinal research on the varied functions of international trade (total trade, exports, and imports) on economic growth at the time of this work. Secondly, our study further enriched the trade-growth literature by combining the various (exports plus imports to GDP ratio, the ratio of exports to GDP, and the ratio of imports to GDP) ways of measuring trade openness to create a new measure to support our argument that multidimensional concept that cannot be summarized to a single measure such as exports plus imports to GDP ratio, the ratio of exports to GDP, and the ratio of imports to GDP. Moreover, by segregating Africa into five sub-regions to investigate the trade-led growth hypothesis, this study adds to the current literature. Thirdly, as a contribution to previous research by Zahonogo (2016), Chang and Mendy (2012), and Gabriel and David (2021), the study adds to the literature by including the new structural economic policy-oriented macroeconomic determinants on Africa and its sub-regions trade-growth nexus by both the static and dynamic estimations. Lastly, with the dynamic sys-GMM, we address the issue of instrument proliferation, which is a serious but often disregarded concern.

Therefore, another objective of this study is also to test whether the relationship between trade openness and economic growth varies on the methodology applied. To do so, we turn Solow's (1956) neoclassical growth model into a static and dynamic panel model, which we then estimate spanning the sample period of 2000 to 2018 using pooled least square, fixed, and random effects, and the system generalized method of the moment. The rest of the paper is laid out as follows: the second section gives a quick overview of the existing literature. Section 3 contains the model formulation, data, and empirical approach. Section 4 discusses the findings and their robustness, and Section 5 concludes the paper with policy implications. 


\section{Literature Review}

\subsection{Theoretical Framework}

According to Grossman and Helpman (2015), theoretical literature reveals many potential links between globalization and growth that stand out in the traditional view. For starters, integrating people and cultures makes it easier for ideas to flow across national lines as foreign ideas can aid in the development of new products, the improvement of existing products, and the production of items at a reduced cost. Second, the integration of product markets through economic relations allows those who innovate or enhance products to move to a market with greater potential where they may earn more money, even if it means competing with foreign competitors. Third, global market integration has ramifications for input pricing and product relative prices in general equilibrium. These pricing variations have an impact on the costs of innovation and the attractiveness of various industrial research approaches. Finally, global interactions boost not only incentives for new knowledge creation, but also those for technology change, with similar repercussions for product diversification.

The nexus between international trade and economic growth has been well proven by theories. The gains that emerging countries will obtain from trading are outlined in classical trade theory, which is based on Adam Smith and David Ricardo's works. In his book Comparative Advantage, Ricardo argues that trade openness allows countries to handle their finite resources and direct output to more efficient sectors. Smith, on the other hand, contends that trade is critical for economic progress because it expands the market and provides each economy with the need to increase return to scale through division of labor (Lam, 2015). According to the Solow (1956) model, technological change is exogenous as a result, and trade policies have no impact on economic growth. New economic growth theories, on the other hand, argue that technological change is an endogenous variable and that trade policies can be integrated (Zahonogo, 2016). Most economists believed that laissez-faire was the greatest way to achieve long-term economic growth from Adam Smith through the early twentieth century. It was supposed that in thriving economies, economic agents engaging in markets, free of government involvement, make all resource allocation decisions. It provided many useful insights into economic development, but it overlooked the need for ongoing, basic technological and industrial upgrading, which distinguishes modern economic growth from premodern economic growth (Kuznets, 1966).

While classical economics recognized the importance of physical and human capital, the prospect of decreasing returns, and the influence of technical advancement (Ramsey, 1928; Schumpeter, 1934), systematic modeling began in the 1940s when some pioneers employed primary factors to building generic models based on aggregate production functions. "Fast, sustainable growth does not happen by accident", according to the Growth Commission (2008), since it necessitates long-term commitment by a country's political leaders, a commitment 
maintained with patience, perseverance, and pragmatism. According to Lin (2012), all successful economies took advantage of the global economy throughout their periods of rapid growth. They did so in at least two ways: first, they imported ideas, technology, and know-how from the rest of the world, a society that has become more open and intertwined since WWII ended. Second, they took advantage of worldwide demand, which created a nearly limitless market for their products.

In recent decades, we have made progress in our knowledge of growth on both the theoretical and empirical fronts. Growth research, on the other hand, continues to encounter substantial methodological obstacles and difficulty in identifying practical policy mechanisms to sustain and enhance growth in specific countries. However, neither theoretical approaches nor empirical analysis has yielded a conclusive result.

\subsection{Empirical Literature}

Greater openness has been shown in numerous studies to have a positive impact on growth. (Amna Intisar et al., 2020; Iyoha \& Okim, 2017; Doan, 2019), for example, found evidence of a favorable association between trade openness and economic growth. Similarly, (Keho, 2017; Hye et al., 2016; Manwa \& Wijeweera, 2016) found a positive association between trade openness and economic growth not only in the long run but also in the short run in their research. The favorable association between trade openness and economic growth is evidence of outward-oriented policies' efficiency. Similarly, there are various ways in which trade openness influences the host economy's economic growth. Trade openness boosts foreign reserves by increasing exports, providing access to a larger market, and boosting productivity, all of which influence total economic growth (Çevik et al., 2019). Kim et al. (2016) used a Cross-Sectional Augmented Autoregressive Lag (CS-ARDL) panel data approach to look at the relationship between trade, economic growth, and growth volatility from 1960 to 2011 for 73 countries. In the long run, more trade improves economic growth while amplifying growth volatility, according to the findings.

Frankel and Romer (1999) construct a model for 1985 using a cross-section of 63 nations. To that end, they create a trading instrument based on geographic characteristics, which they then use to investigate the income response to trade. The data show that trade and size have significant beneficial effects on income. According to the authors, these effects are resistant to multiple parameters, samples, and techniques. Jouini (2015) utilizes the Pooled Mean Group (PMG) estimate approach for the six Gulf Cooperation Council (GCC) countries for the annual study period 1980-2010 to explore the links between economic growth and openness to trade. The findings reveal that in the short and long run, trade openness boosts economic growth, implying a cointegration association between the factors of interest. The data is unaffected by a multitude of trade openness indicators and other model assumptions, showing that the GCC region's link 
between economic growth and international trade openness is not weak. Abendin and Duan (2021) explore the role of the digital economy and international trade on Africa's economic growth using POLS, random and fixed effects, and sys-GMM models. Using merchandise trade as a proxy for trade openness, the findings revealed that trade has a large positive impact on economic development in Africa. Malefane and Odhiambo (2018) looked into the dynamic effect of trade openness on South African economic growth. Their long-term empirical findings reveal that when the ratio of total trade to GDP had a positive and significant impact on economic growth, but not when alternative proxies were used. Their short-run empirical data showed that trade openness had a beneficial influence on economic growth when the first three proxies of openness were utilized, but not when the trade openness index was used. They concluded that encouraging policies that boost trade was important for the South African economy based on these findings.

The literature also shows that trade openness has an indirect impact on economic growth via numerous channels. Huchet-Bourdon et al. (2018) used the GMM estimation approach to study the openness-growth connection in an unbalanced panel of 169 countries from 1988 to 2014, adopting quality exports and variety exports as openness channels. According to their findings, the GDP effect of trade openness reflects a non-linear pattern. Their findings also reveal that the positive impact of trade openness on economic growth is reliant on the quality and diversity of a country's export basket. According to Mbate (2015), diversifying exports necessitates development planning via an effective state-led trade policy that encourages value addition in new economic activities other than traditional commodities. Ramzan et al. (2019) used a sample of 82 nations from 1980 to 2014 to show that the impact of openness in the economic growth process is reliant on total factor productivity. As a result, economies with higher total factor productivity may be in a far better position to reap the benefits of trade openness than economies with lower total factor productivity. Gabriel and David (2021) and Huang and Chang (2014) analyze the effect of trade and financial openness on economic growth using panel data. Their results show there is no simultaneous openness hypothesis on economic growth. Their findings imply that while trade openness has no straightforward impact on GDP growth, it is influenced by the extent of stock market development. This followed the pattern that financial development, according to Beck (2002), Stiglitz (2004), and Aghion and Howitt (2005), is a significant route influencing the trade-growth link.

Some empirical studies, on the other hand, indicate that trade openness is harmful to economic growth. That is, if an economy concentrates on industries with dynamic comparative disadvantages, market defects, unstable foreign demand, and ineffective trade policy, trade openness may slow economic growth (Farahane \& Hesmati, 2020). Studies by Levine and Renelt (1992), Rodriguez and Rodrik (2000), Yanikkaya (2003) revealed that establishing a significant positive re- 
lationship between openness and growth is challenging and that there may even be a negative relationship. For instance, Trade openness is not the key engine of Asia's "miracle" economic growth, according to Trejos and Barboza (2015). Ulaşan (2012) explores the long-run trade openness-economic growth connection in OECD and non-OECD countries from 1960 to 2000 using cross-country regressions. Many variables related to openness have a significant positive impact on the economy. When other factors are added to the model, the result vanishes, revealing the rigidity of the links between trade openness and economic growth for the chosen group of countries. Among empirical studies, some studies find a mixed effect of trade openness on economic growth. Employing data from 1975 to 2017, Ijirshar (2019) analyses the influence of trade on growth in ECOWAS countries. The findings demonstrate that trade openness has good long-term effects on growth in ECOWAS countries, but ambiguous short-term ones.

Adhikary (2011) points out that more trade openness leads to greater exchange rate depreciation, which reduces aggregate input supply by raising the prices of imported commodities utilized in production. As a result, domestic output tends to decline, making the domestic market less competitive. Furthermore, according to Rodrik (1992), openness can exacerbate macroeconomic instability by increasing inflation, weakening currency rates, and causing a balance-of-payments crisis. Alege and Osabuohien (2015), on the other hand, looked into the relationship between the exchange rate and international rate trade in SSA. The investigation revealed that changes in the exchange rate have little effect on exports and imports. As a result, in light of the region's economic structures and export compositions, depreciation of currencies may not have the desired results. Similarly, while the balance of payments may worsen, devaluation has little effect on imports.

In summing, African studies conducted by Le Goff and Singh (2014), Zahonogo (2016), Chang and Mendy (2012), Huchet-Bourdon et al. (2018), and Gabriel and David (2021) examined a long timeframe spanning over 3 decades for policy recommendations, but the short-timeframe is a lacuna in literature. Therefore, this study emphasizes on essential concerns of short-time-horizon for policy advisors in emerging countries, in obtaining high growth rates as a key policy goal. Furthermore, previous studies by Ijirshar (2019), Tinta et al. (2018), Moyo and Khobai (2018), Iyoha and Okim (2017), Farahane and Hesmati (2020), and Manwa and Wijeweera (2016) empirically examined the effect of trade openness on economic growth on ECOWAS or SADC regions in Africa without looking at the comparative trade-growth link in Africa regions. Hence, this study fills this gap in the literature.

\section{Methodology}

\subsection{Research Model}

The neoclassical growth model (Cobb \& Douglas, 1928; Solow, 1956) lays the 
theoretical groundwork for studying the major sources of economic growth. Technology, capital, and labor are the primary determinants of production activities, according to this theory. The structure for the Cobb-Douglas production function can be expressed as follows:

$$
Y_{i t}=A_{i t}^{\theta 1 i} K_{i t}^{\theta 2 i} L_{i t}^{\theta 3 i} \varepsilon^{u i t}
$$

where $Y$ denotes output, $A$ denotes technical development, $K$ denotes capital, $L$ is labor, and $\varepsilon$ is the stochastic term capturing unobserved variables. The subscripts $i$ and $t$ denote countries and time, respectively. The elasticity of each variable to economic growth is represented by the exponents of the variables. As a result of instituting constant return to scale in Equation (1), the following is our augmented growth model for empirical investigation:

$$
\mathrm{GDP}_{i t}=\beta_{0}+\beta_{1} \mathrm{OPEN}_{i t}^{\prime}+\beta_{2} \mathrm{GFCF}_{i t}+\beta_{3} \mathrm{LAB}_{i t}+\beta_{4} C_{i t}^{\prime}+\delta_{i}+\varphi_{i}+\varepsilon_{i t}
$$

GDP per capita is the gross domestic product. Any of the four proxies for trade openness OPEN 'is represented by the word OPEN1, OPEN2, OPEN3, and OPEN4 respectively. GFCF stands for gross fixed capital formation, LAB represents total workforce and $C^{\prime}$ denotes the vector of control variables. Also, the constant term, regional dummies, year dummies, and stochastic error term are represented by $\beta_{0}+\varphi_{i}+\varepsilon_{i t}$, while the variables' corresponding coefficients are represented by $\beta$ s $(1,2,3$, and 4$)$.

To eliminate heteroscedasticity, we converted all of the variables to natural logarithms and calculated the elasticity straight from the slope coefficients. As a result, Equation (2) can be rewritten as the production function's linear natural $\log$ form:

$$
\operatorname{InGDP}_{i t}=\beta_{0}+\beta_{1} \operatorname{InOPEN}_{i t}^{\prime}+\beta_{2} \operatorname{InGFCF}_{i t}+\beta_{3} \operatorname{InLAB}_{i t}+\beta_{4} C_{i t}^{\prime}+\delta_{i}+\varphi_{i}+\varepsilon_{i t}
$$

\subsection{Variable Description and Data}

Annual panel data from 52 African countries were used in this study, which spans the years 2000 to 2018 . The panel data was then further sub-sampled into Africa's five regional groups (Table A1). The study's data came from the World Bank's World Development Indicators. The primary variables in this study are GDP per capita, and is used to evaluate economic growth; trade openness (OPEN'), which is measured using four distinct indicators: imports plus exports to GDP (OPEN1), imports to GDP (OPEN2), exports to GDP (OPEN3), and the composite trade openness index (OPEN4). Also, gross domestic fixed capital formation (GFCF) represents capital stock; labor force denotes total workforce (LAB); exchange rate connotes official exchange rate determined by national authorities (EXC); financial development connotes domestic credit provided by banks (FD); foreign direct investment denotes foreign investment inflows (FDI); consumer price index represents consumer price index (CPI) (Table A2).

\subsection{Estimation Procedures}

Taking into consideration that $\mathrm{N}>\mathrm{T}$ that is the number of cross-sections (52) is 
greater than the period (19 years). We employ the static and the dynamic panel model to consistently analyze the effect of trade openness on economic growth similar to the study of (Abendin \& Duan, 2021; Iyoha \& Okim, 2017). The static model comprises the Pooled Ordinary Least Square (POLS), which ignores the heterogeneities problem, and the Random Effects Model (REM), which takes into consideration heterogeneities. Also, the dynamic model represents the System Generalized Methods of Moment (sys-GMM) model by Arellano and Bover (1995) and Blundell and Bond (1998), which account for endogeneity by using instrumental variables. The idea behind the sys-GMM information-generating mechanism is that it can be dynamic, with earlier realizations of the dependent variable influencing the current one. Furthermore, the regressors are not exogenous and can be linked to previous and likely current stochastic term realizations.

Following the lead of Zahonogo (2016), Jouini (2015), and Ulaşan (2015), we used the measures of trade intensity as our trade openness variable to investigate the impact of actual globalization on growth. The fact that trade intensity measurements are not constructed is a significant advantage. From objective data sources, trade intensity proxies are more precisely defined, well-measured, and more easily accessible. All three proxy indicators of trade openness are, by definition, directly related. As a result, for robustness checks, and collinearity problems we use them separately. Considering the studies of Hye et al. (2016) and Hye and Lau (2015), a composite trade openness index (TOI) is included in addition to the trade share measurements. The TOI is calculated using Principal Component Analysis (PCA) to determine the weight of each indicator. The principle component approach is a method for lowering the density of data while maximizing interpretability and avoiding data redundancy. It accomplishes this by generating new uncorrelated variables that sequentially maximize variance (Jolliffe \& Cadima, 2016). The method has been used to calculate the financial development index Ngimanang (2020) and the digital economy index Abendin and Duan (2021), among others. The composite index function can be written as follows:

$$
\text { OPEN4 }=f\left(\mathrm{OPEN1}_{i t}, \mathrm{OPEN}_{i t}, \mathrm{OPEN}_{i t}\right)
$$

where; OPEN4 represents the composite trade openness index from OPEN1, OPEN2, and OPEN3.

The research sample is also broken down into five sub-regions: Southern Africa, Western Africa, Central Africa, Eastern Africa, and Northern Africa. This allows us to compare the research results to see if regional factors play a role in our conclusions. The pooled OLS is used to estimate both the entire sample and the sub-regional sample. Although the REM and sys-GMM techniques are only used on the complete sample due to the small amount of data, they are not suitable for sub-regions estimation.

Furthermore, a key but often neglected issue in the sys-GMM model, particu- 
larly those based on small samples, is that the estimators suffer from the abundance of instruments (Roodman, 2009). Furthermore, because there are so many instruments, over-identification tests are probably ineffectual (Bowsher, 2002). We employ Hansen and difference-in-Hansen tests to verify instrument accuracy as we use two-step GMM. These test data are highly prone to instrument proliferation, even if the number of instruments is reduced to less than the number of countries. As a result, we run these tests at Roodman's (2009) recommended 0.5 or 0.10 values.

Finally, we look at whether the error term is serially linked to ensure that our model specification is valid. The test is done on the first-differenced error term. On a second-order basis, the null hypothesis states that they are uncorrelated. Our model formulation is supported by the failure to reject the null hypothesis in both cases.

\section{Empirical Results and Discussion}

\subsection{Results from Pooled Ordinary Least Square (POLS)}

Table 1 summarizes the results of full sample estimators. The results of each trade openness measure are listed in the following order: OPEN1-OPEN4. According to our findings, the coefficients of each measure of trade openness are statistically significant and have a positive sign. On the other hand, OPEN2 displays a negative sign. Trade openness, as measured by total trade contribution, exports, and the trade openness index, appears to increase GDP per capita, according to this study. Imports, on the other hand, harm GDP per capita. A 10\% increase in trade openness raises GDP per capita by $4.6 \%, 7.8 \%$, and $4.8 \%$ on average ceteris paribus, attributed to the favorable effects of OPEN1, OPEN2, and OPEN4. However, things being equal, a $10 \%$ increase in OPEN3 lowers GDP by $4.3 \%$. This conclusion shows that trade openness (trade, exports, and the trade openness index) has a positive direct impact on GDP, which is under other research, such as (Were, 2015; Dreher, 2006). The impact of imports on GDP per capita, on the other hand, is consistent with earlier research, such as (Madsen, 2009; Kim, 2011). Furthermore, the overall result is consistent with the theoretical theory that increased international trade leads to greater economic growth. This finding supports the famed Grossman and Helpman (2015) trade theories, which all contend that international trade boosts economic prosperity.

The results as shown in Table 1, reveal that the GFCF coefficient for OPEN1OPEN4 is positive and statistically significant at a $1 \%$ significance level, which is consistent with our prior information. On average, a $10 \%$ rise in GFCF improves GDP per capita by $4.2 \%, 6.7 \%, 2.5 \%$, and $2.5 \%$, respectively. This emphasizes the significance of gross fixed capital formation as a driver of economic growth. Domestic investment is thus a key aspect in increasing Africa's economic growth. As a result, an increase in capital spending will boost Africa's growth. Gabriel and David (2021), Zahonogo (2016), Iyoha and Okim (2017), 
Table 1. Pooled ordinary least square results, dependent variable InGDPPC.

\begin{tabular}{|c|c|c|c|c|}
\hline Variables & OPEN1 & OPEN2 & OPEN3 & OPEN4 \\
\hline OPEN' & $\begin{array}{l}0.464^{\star * \star} \\
(-0.068)\end{array}$ & $\begin{array}{l}-0.439^{* * *} \\
(-0.0701)\end{array}$ & $\begin{array}{l}0.782^{\star * *} \\
(-0.0398)\end{array}$ & $\begin{array}{l}0.488^{\star * *} \\
(-0.0248)\end{array}$ \\
\hline InGFCF & $\begin{array}{l}0.425^{\star * *} \\
(-0.0615)\end{array}$ & $\begin{array}{l}0.679^{\star * *} \\
(-0.0606)\end{array}$ & $\begin{array}{l}0.252^{\star * *} \\
(-0.0525)\end{array}$ & $\begin{array}{l}0.252^{\star * *} \\
(-0.0525)\end{array}$ \\
\hline InLAB & $\begin{array}{l}-0.183^{\star * *} \\
(-0.0181)\end{array}$ & $\begin{array}{l}-0.294^{* * *} \\
(-0.0185)\end{array}$ & $\begin{array}{l}-0.163^{\star * *} \\
(-0.0144)\end{array}$ & $\begin{array}{l}-0.163^{* * *} \\
(-0.0144)\end{array}$ \\
\hline InEXC & $\begin{array}{l}-0.0250^{*} \\
(-0.0132)\end{array}$ & $\begin{array}{l}-0.0513^{* * *} \\
(-0.0133)\end{array}$ & $\begin{array}{l}-0.0221^{\star} \\
(-0.0114)\end{array}$ & $\begin{array}{l}-0.0221^{\star} \\
(-0.0114)\end{array}$ \\
\hline InFD & $\begin{array}{l}0.325^{\star * *} \\
(-0.0349)\end{array}$ & $\begin{array}{l}0.376^{\star * *} \\
(-0.035)\end{array}$ & $\begin{array}{l}0.298^{\star * *} \\
(-0.0301)\end{array}$ & $\begin{array}{l}0.298^{* * *} \\
(-0.0301)\end{array}$ \\
\hline InFDI & $\begin{array}{l}-0.401^{\star * *} \\
(-0.0568)\end{array}$ & $\begin{array}{l}-0.225^{\star * *} \\
(-0.0584)\end{array}$ & $\begin{array}{l}-0.363^{\star * *} \\
(-0.0483)\end{array}$ & $\begin{array}{l}-0.363^{* * *} \\
(-0.0483)\end{array}$ \\
\hline InCPI & $\begin{array}{l}-0.0214 \\
(-0.122)\end{array}$ & $\begin{array}{l}-0.0186 \\
(-0.122)\end{array}$ & $\begin{array}{c}0.0491 \\
(-0.105)\end{array}$ & $\begin{array}{c}0.0491 \\
(-0.105)\end{array}$ \\
\hline NORTHERN AFRICA & $\begin{array}{l}0.505^{\star * *} \\
(-0.0875)\end{array}$ & $\begin{array}{l}0.248^{\star * *} \\
(-0.0888)\end{array}$ & $\begin{array}{l}0.529^{\star * *} \\
(-0.0745)\end{array}$ & $\begin{array}{l}0.529^{* * *} \\
(-0.0745)\end{array}$ \\
\hline WESTERN AFRICA & $\begin{array}{l}-0.337^{\star * *} \\
(-0.0815)\end{array}$ & $\begin{array}{l}-0.461^{\star * *} \\
(-0.0814)\end{array}$ & $\begin{array}{l}-0.216^{\star * *} \\
(-0.0705)\end{array}$ & $\begin{array}{l}-0.216^{\star * *} \\
(-0.0705)\end{array}$ \\
\hline CENTRAL AFRICA & $\begin{array}{c}0.176^{\star} \\
(-0.0961)\end{array}$ & $\begin{array}{c}0.0109 \\
(-0.0971)\end{array}$ & $\begin{array}{c}0.192^{\star *} \\
(-0.0827)\end{array}$ & $\begin{array}{c}0.192^{\star *} \\
(-0.0827)\end{array}$ \\
\hline EASTERN AFRICA & $\begin{array}{l}-0.398^{\star * \star} \\
(-0.0837)\end{array}$ & $\begin{array}{l}-0.596^{\star * *} \\
(-0.0821)\end{array}$ & $\begin{array}{c}-0.0989 \\
(-0.0736)\end{array}$ & $\begin{array}{c}-0.0989 \\
(-0.0736)\end{array}$ \\
\hline Constant & $\begin{array}{l}7.145^{\star \star \star} \\
(-0.715)\end{array}$ & $\begin{array}{c}11.34^{* * *} \\
(-0.7)\end{array}$ & $\begin{array}{l}6.275^{\star * *} \\
(-0.568)\end{array}$ & $\begin{array}{l}8.850^{* * *} \\
(-0.545)\end{array}$ \\
\hline Year dummies & Yes & Yes & Yes & Yes \\
\hline Observations & 988 & 988 & 988 & 988 \\
\hline R-squared & 0.56 & 0.557 & 0.672 & 0.672 \\
\hline F statistics & 42.1 & 41.54 & 67.54 & 97.53 \\
\hline
\end{tabular}

Notes: ${ }^{* *},{ }^{* *}$, and ${ }^{*}$ indicate statistical significance at the $1 \%, 5 \%$, and $10 \%$ levels, respectively; $t$-statistics (in parentheses). Source: Authors' compilation.

and Huchet-Bourdon et al. (2018) have all reported similar findings. The GFCF coefficient for OPEN1-OPEN4 is positively significant at a $1 \%$ significance level, as shown in Table 1, which is consistent with our previous findings. On average, 
a $10 \%$ rise in GFCF improves GDP per capita by $4.2 \%, 6.7 \%, 2.5 \%$, and $2.5 \%$, respectively. This stresses the importance of gross fixed capital formation as a driver of economic development. Domestic investment is thus a key aspect in increasing Africa's economic growth. As a result, an increase in capital spending is per the new structural economic by Lin (2012) will boost Africa's production. However, LAB, a significant factor of GDP coefficients for all the trade openness model specifications, indicates an adverse and statistically significant at a $1 \%$ significance level. This outcome recommends that an increase of $10 \%$ in the labor force decreases GDP per capita by 1.8\%, 2.9\%, 1.6\%, and 1.6\% for OPEN1OPEN4 respectively on average ceteris paribus. Our findings are consistent with the results by Abendin and Duan (2021) and inconsistent with Adeleye and Eboagu (2019), who showed positive economic growth in the labor force.

Other control factors show that EXC has a negative influence on economic growth at a $1 \%$ and $10 \%$ level for OPEN1-OPEN4 on average ceteris paribus. The negative influence of the exchange rate on economic growth may be caused by currency depreciation, which makes goods from Africa more affordable on the global market. Because lower prices raise demand for commodities, more trade openness slows economic growth. This finding is consistent with that of Adhikary (2011) and Rodrik (1992), who claim that openness can exacerbate macroeconomic instability by increasing inflation, depreciating currency rates, and causing a balance-of-payments crisis. In contrast to the new structural economic theory by Lin (2012), which recommends macroeconomic stability as a promoter of economic progress. At a $1 \%$ significance level, FD for all trade openness indicators indicates a positive and statistically significant effect on average, ceteris paribus. This outcome also confirmed the important role played by the local financial sector in Africa's economic growth. The good influence of financial development on economic growth implies that domestic bank funds are channeled to productive activity, resulting in positive benefits for African economies. This discovery is consistent with the findings of Adjasi et al. (2012). FDI exhibits a negative and statistically significant at a $1 \%$ significance level effect on Africa's growth for all trade openness measures. Similar studies by Gabriel and David (2021), Duodu and Baidoo (2020), Stiglitz (2004), and Yanikkaya (2003) reported negative impacts of foreign direct investments on GDP per capita, in contrast with past studies such as (Wang \& Wong, 2011; Beugelsdijk et al., 2008). CPI shows a mixed and statistically insignificant effect on GDP per capita for all measures of openness in Africa.

For the regional dummies, the GDP of Central African countries is higher than that of Eastern African countries by $28.56 \%$ on average, ceteris paribus, for all indicators of openness. In contrast, GDP in Northern Africa (base region), Western Africa, and Southern Africa is $12.25 \%, 77.18 \%$, and $49.49 \%$ lower than in Eastern Africa, respectively, things being equal, the North Africa result is statistically significant at $1 \%$ for all the measures of trade openness on growth. The goodness-of-fit of OPEN1-OPEN4 found that the explanatory fac- 
tors explained $56 \%, 55.7 \%, 76.2 \%$, and $67.2 \%$ of the dependent variable variation, respectively, after controlling for the year dummies. The F-statistic, on the other hand, suggests that the factors are both important in explaining economic growth.

Table 2 documented the results for the sub-regions regressions using the POLS estimator. The outcomes in Table 2 show all measures of trade openness have a positive and statistically significant effect at a $1 \%$ significance level on GDP per capita for Northern Africa countries. These findings suggest that trade openness is an elixir of economic growth in Northern Africa and is in line with the classical growth theory of Smith and Ricardo, the new structural economic theory by Lin (2012), and the study by Sghaier (2020). On the input variables, the GFCF is negative and statistically significant at a $1 \%$ significance level on GDP per capita. These results postulate gross fixed capital formation has an unfavorable effect on economic growth and hence, Northern Africa nations need to follow the theoretical hint of Lin (2012) towards increasing investment as a booster of economic growth. LAB shows a positive effect on GDP per capita. However, only OPEN1 is statistically significant at a $1 \%$ level. These findings suggest that an enhancement of the labor force will significantly promote growth in Northern Africa. On the control variables, EXC shows a positive and insignificant effect on GDP per capita. These findings postulate that an improvement in the exchange rate will improve the critical structure of economic growth. FD shows a mixed effect on economic growth. However, OPEN3 shows a positive and insignificant effect on GDP per capita. The results suggest that financial development does not spur economic growth in Northern Africa and an increase in financial development through exports will produce a significant result on growth. FDI displays a negative and statistically significant impact on GDP at a $1 \%$ significance level. These results postulate foreign investment is critical to economic growth. This finding contrasts with the study by Alfaro et al. (2010) who finds FDI enhances growth in Northern Africa. CPI shows a mixed effect on economic growth with OPEN1 being positive and statistically significant at a 5\% significance level.

Table 2, results show trade openness has a negative and statistically significant impact on the GDP per capita of Western African countries. Though, OPEN3 shows a positive and non-significant impact on economic growth. These findings postulate international trade harms GDP per capita in the Western regions. This finding is similar to Tinta et al.'s (2018) study and contrasts the theory of Grossman and Helpman (2015), the new structural economic view of Lin (2012), the classical theory of Smith and Ricardo, and the results by Ijirshar (2019) on ECOWAS countries. An improvement in exports (OPEN3) will significantly impact economic growth. Among the input variables, GFCF show positive and statistically significant results on economic growth. While, LAB exhibits a positive and insignificant effect on GDP per capita, but OPEN2 shows a negative impact on GDP per capita. These findings suggest GFCF is a significant 
Table 2. Sub-regions pooled OLS results, dependent variable InGDPPC.

\begin{tabular}{|c|c|c|c|c|c|c|c|c|}
\hline \multirow{2}{*}{ Variables } & \multicolumn{4}{|c|}{ Northern Africa } & \multicolumn{4}{|c|}{ Western Africa } \\
\hline & OPEN1 & OPEN2 & OPEN3 & OPEN4 & OPEN1 & OPEN2 & OPEN3 & OPEN4 \\
\hline \multirow{2}{*}{ OPEN' } & $1.518^{\star * \star}$ & $1.297^{\star * *}$ & $1.133^{\star * \star}$ & $0.580^{\star * *}$ & $-0.199^{* *}$ & $-0.379^{* * *}$ & 0.0991 & $-0.0822^{* *}$ \\
\hline & $(0.145)$ & (0.198) & $(0.113)$ & $(0.0887)$ & $(0.0940)$ & $(0.0841)$ & $(0.0821)$ & $(0.0388)$ \\
\hline \multirow{2}{*}{ InGFCF } & $-0.649^{* * *}$ & $-0.892^{* * *}$ & $-0.609^{* * *}$ & $-0.892^{\star * *}$ & $0.183^{\star *}$ & $0.222^{\star * *}$ & $0.161^{\star}$ & $0.183^{\star *}$ \\
\hline & $(0.174)$ & $(0.204)$ & $(0.178)$ & $(0.204)$ & $(0.0833)$ & $(0.0816)$ & $(0.0833)$ & $(0.0833)$ \\
\hline \multirow{2}{*}{ InLAB } & $0.158^{\star \star \star}$ & 0.0822 & 0.0711 & 0.0822 & 0.00406 & -0.0336 & 0.0290 & 0.00406 \\
\hline & $(0.0582)$ & $(0.0708)$ & $(0.0551)$ & $(0.0708)$ & $(0.0270)$ & $(0.0277)$ & $(0.0257)$ & $(0.0270)$ \\
\hline \multirow{2}{*}{ InEXC } & 0.0284 & 0.0448 & 0.0509 & 0.0448 & $-0.0313^{\star}$ & $-0.0296^{\star}$ & -0.0281 & $-0.0313^{*}$ \\
\hline & $(0.0434)$ & $(0.0514)$ & $(0.0440)$ & $(0.0514)$ & $(0.0176)$ & $(0.0171)$ & $(0.0177)$ & $(0.0176)$ \\
\hline \multirow{2}{*}{ InFD } & $-0.129^{\star}$ & $-0.232^{\star *}$ & 0.0992 & $-0.232^{\star \star}$ & $0.484^{* * *}$ & $0.493^{* * *}$ & $0.443^{\star * *}$ & $0.484^{* * *}$ \\
\hline & $(0.0747)$ & $(0.108)$ & $(0.0678)$ & $(0.108)$ & $(0.0480)$ & $(0.0461)$ & $(0.0491)$ & $(0.0480)$ \\
\hline \multirow{2}{*}{ InFDI } & $-0.915^{\star * *}$ & $-1.078^{\star * *}$ & $-0.739^{* * *}$ & $-1.078^{* * *}$ & 0.0574 & $0.156^{*}$ & -0.0171 & 0.0574 \\
\hline & $(0.153)$ & $(0.184)$ & $(0.156)$ & $(0.184)$ & $(0.0841)$ & $(0.0844)$ & $(0.0793)$ & $(0.0841)$ \\
\hline \multirow{2}{*}{ InCPI } & $1.042^{\star \star}$ & -0.252 & $1.313^{\star *}$ & -0.252 & 0.582 & 0.757 & 0.242 & 0.582 \\
\hline & $(0.495)$ & $(0.549)$ & $(0.519)$ & $(0.549)$ & $(0.504)$ & $(0.488)$ & $(0.505)$ & $(0.504)$ \\
\hline \multirow{2}{*}{ Const. } & -1.128 & $8.934^{* * *}$ & 0.205 & $13.47^{\star * *}$ & 3.176 & 3.139 & 3.465 & 2.354 \\
\hline & $(2.834)$ & $(2.905)$ & $(2.834)$ & $(2.582)$ & (2.093) & $(2.036)$ & $(2.109)$ & $(2.137)$ \\
\hline Observations & 133 & 133 & 133 & 133 & 285 & 285 & 285 & 285 \\
\hline R-squared & 0.647 & 0.505 & 0.632 & 0.505 & 0.427 & 0.457 & 0.421 & 0.427 \\
\hline F statistics & 32.70 & 18.24 & 30.71 & 30.71 & 29.48 & 33.37 & 28.74 & 28.74 \\
\hline
\end{tabular}

Notes: ${ }^{* *},{ }^{* *}$, and ${ }^{*}$ indicate statistical significance at the $1 \%, 5 \%$, and $10 \%$ levels, respectively; $t$-statistics (in parentheses). Source: Authors' compilation.

\begin{tabular}{|c|c|c|c|c|c|c|c|c|}
\hline \multirow{2}{*}{ Variables } & \multicolumn{4}{|c|}{ Central Africa } & \multicolumn{4}{|c|}{ Eastern Africa } \\
\hline & OPEN1 & OPEN2 & OPEN3 & OPEN4 & OPEN1 & OPEN2 & OPEN3 & OPEN4 \\
\hline \multirow{2}{*}{ OPEN' } & $0.991^{\star * *}$ & $-0.915^{\star * *}$ & $1.329^{* * *}$ & $0.877^{\star \star \star *}$ & -0.133 & $-0.822^{\star * *}$ & $0.354^{* * *}$ & -0.0833 \\
\hline & $(0.262)$ & $(0.261)$ & $(0.131)$ & $(0.0861)$ & $(0.137)$ & $(0.146)$ & $(0.0797)$ & $(0.0857)$ \\
\hline \multirow{2}{*}{ InGFCF } & $0.435^{\star *}$ & $1.310^{\star * *}$ & 0.183 & 0.183 & $1.131^{\star * *}$ & $1.277^{\star * *}$ & $0.821^{* * *}$ & $1.131^{* * *}$ \\
\hline & $(0.197)$ & $(0.188)$ & $(0.140)$ & $(0.140)$ & $(0.124)$ & $(0.112)$ & $(0.123)$ & $(0.124)$ \\
\hline \multirow{2}{*}{ InLF } & $-0.484^{\star * *}$ & $-0.607^{\star * *}$ & $-0.314^{\star * *}$ & $-0.314^{\star * *}$ & $-0.321^{\star * *}$ & $-0.408^{\star * *}$ & $-0.256^{\star * *}$ & $-0.321^{\star * *}$ \\
\hline & $(0.0623)$ & $(0.0541)$ & $(0.0515)$ & $(0.0515)$ & $(0.0307)$ & $(0.0299)$ & $(0.0261)$ & $(0.0307)$ \\
\hline \multirow{2}{*}{ InEXC } & $0.634^{* * *}$ & $0.618^{* * *}$ & $0.240^{\star * *}$ & $0.240^{\star * *}$ & -0.00724 & $-0.0403^{\star}$ & -0.00618 & -0.00724 \\
\hline & $(0.0860)$ & $(0.0886)$ & $(0.0814)$ & $(0.0814)$ & $(0.0246)$ & $(0.0236)$ & $(0.0232)$ & $(0.0246)$ \\
\hline
\end{tabular}




\section{Continued}

\begin{tabular}{|c|c|c|c|c|c|c|c|c|}
\hline \multirow{2}{*}{ InFD } & $0.438^{* * *}$ & $0.171^{\star}$ & $0.650^{* * *}$ & $0.650^{* * *}$ & $0.716^{* * *}$ & $0.870^{\star * *}$ & $0.536^{\star * *}$ & $0.716^{\star * *}$ \\
\hline & $(0.109)$ & $(0.102)$ & $(0.0872)$ & $(0.0872)$ & $(0.0747)$ & $(0.0683)$ & $(0.0684)$ & $(0.0747)$ \\
\hline \multirow{2}{*}{ InFDI } & $-0.317^{\star * *}$ & -0.138 & -0.154 & -0.154 & $0.308^{*}$ & $0.578^{\star * *}$ & 0.0146 & $0.308^{*}$ \\
\hline & $(0.119)$ & $(0.124)$ & $(0.0953)$ & $(0.0953)$ & $(0.160)$ & $(0.149)$ & $(0.149)$ & $(0.160)$ \\
\hline \multirow{2}{*}{ InCPI } & $1.466^{* * *}$ & $0.780^{\star *}$ & $1.320^{* * *}$ & $1.320^{* * *}$ & $-2.446^{\star * *}$ & $-2.030^{\star * *}$ & $-2.257^{\star * *}$ & $-2.446^{\star * *}$ \\
\hline & $(0.368)$ & $(0.383)$ & $(0.289)$ & $(0.289)$ & $(0.503)$ & $(0.477)$ & $(0.484)$ & $(0.503)$ \\
\hline \multirow{2}{*}{ Constant } & -1.764 & $8.022^{* * *}$ & -1.626 & $2.993^{\star}$ & $16.70^{\star * *}$ & $17.30^{* * *}$ & $15.41^{* * *}$ & $16.15^{\star * *}$ \\
\hline & $(2.405)$ & $(2.362)$ & $(1.648)$ & $(1.570)$ & $(2.187)$ & $(2.035)$ & $(2.089)$ & $(2.177)$ \\
\hline Observations & 152 & 152 & 152 & 152 & 228 & 228 & 228 & 228 \\
\hline R-squared & 0.640 & 0.636 & 0.770 & 0.770 & 0.761 & 0.790 & 0.780 & 0.761 \\
\hline F statistics & 36.62 & 35.87 & 68.91 & 68.91 & 100.00 & 118.18 & 111.18 & 111.18 \\
\hline
\end{tabular}

Notes: ${ }^{* *},{ }^{* *}$, and ${ }^{*}$ indicate statistical significance at the $1 \%, 5 \%$, and $10 \%$ levels, respectively; $t$-statistics (in parentheses). Source: Authors' compilation.

\begin{tabular}{|c|c|c|c|c|}
\hline \multirow{2}{*}{ Variables } & \multicolumn{4}{|c|}{ Southern Africa } \\
\hline & OPEN1 & OPEN2 & OPEN3 & OPEN4 \\
\hline \multirow{2}{*}{ OPEN' } & $-0.468^{\star \star}$ & $-0.974^{\star * *}$ & $0.695^{\star * *}$ & $-0.153^{\star \star}$ \\
\hline & $(0.187)$ & $(0.127)$ & $(0.121)$ & $(0.0610)$ \\
\hline \multirow{2}{*}{ InGFCF } & $0.919^{\star * *}$ & $0.990^{\star * *}$ & $0.652^{\star * *}$ & $0.919^{* * *}$ \\
\hline & $(0.104)$ & $(0.0866)$ & $(0.0924)$ & $(0.104)$ \\
\hline \multirow{2}{*}{ InLF } & $-0.240^{\star * *}$ & $-0.324^{\star * *}$ & $-0.108^{\star \star \star}$ & $-0.240^{\star * *}$ \\
\hline & $(0.0406)$ & $(0.0343)$ & $(0.0327)$ & $(0.0406)$ \\
\hline \multirow{2}{*}{ InEXC } & 0.0153 & 0.00751 & $0.0380^{\star *}$ & 0.0153 \\
\hline & $(0.0172)$ & $(0.0150)$ & $(0.0159)$ & $(0.0172)$ \\
\hline \multirow{2}{*}{ InFD } & $0.894^{\star * *}$ & $0.843^{\star * *}$ & $0.866^{* * *}$ & $0.894^{\star * *}$ \\
\hline & $(0.0542)$ & $(0.0485)$ & $(0.0510)$ & $(0.0542)$ \\
\hline \multirow{2}{*}{ InFDI } & $-0.545^{\star * *}$ & $-0.419^{\star * *}$ & $-0.518^{\star \star \star}$ & $-0.545^{\star \star \star}$ \\
\hline & $(0.0740)$ & $(0.0678)$ & $(0.0693)$ & $(0.0740)$ \\
\hline \multirow{2}{*}{ InCPI } & 0.186 & 0.157 & 0.0736 & 0.186 \\
\hline & $(0.116)$ & $(0.103)$ & $(0.110)$ & $(0.116)$ \\
\hline \multirow{2}{*}{ Constant } & $8.065^{\star * *}$ & $10.78^{\star * *}$ & $2.797^{\star * *}$ & $5.993^{\star * *}$ \\
\hline & $(1.292)$ & $(0.974)$ & $(0.867)$ & $(0.806)$ \\
\hline Observations & 190 & 190 & 190 & 190 \\
\hline R-squared & 0.722 & 0.783 & 0.757 & 0.722 \\
\hline F statistics & 67.63 & 93.63 & 80.91 & 80.91 \\
\hline
\end{tabular}

Notes: ${ }^{\star *},{ }^{* *}$, and ${ }^{\star}$ indicate statistical significance at the $1 \%, 5 \%$, and $10 \%$ levels, respectively; $t$-statistics (in parentheses). Source: Authors' compilation. 
determinant of GDP per capita, but the labor force is not a significant determinant of economic growth. EXC reveals that GDP per capita has a negative and statistically significant influence. At a $1 \%$ significance level, FD implies a significantly positive result. On average ceteris paribus, FDI has a mixed influence on economic growth, with the OPEN2 showing a statistically significant positive impact on GDP at a 10\% significance level. While the Consumer Price Index (CPI) has a positive but statistically insignificant effect on GDP.

In Table 2, trade openness shows a mixed and statistically significant impact on GDP per capita in Central Africa regions. These results indicate that OPEN1, OPEN3, and OPEN4 promote economic growth whereas, OPEN2 is unfavorable on GDP per capita. GFCF, EXC, FD, and CPI positively impacted economic growth on all measures of trade openness. The positive effect of exports, domestic capital, and exchange rate on growth is similar to the findings of Yusoff and Nulambeh (2016). On the contrary, LAB and FDI negatively impacted GDP per capita. These findings suggest Central Africa regions need to attract foreign investments, improve their labor force and decrease importation to promote GDP per capita.

Table 2 shows trade openness has a mixed effect on GDP per capita. The overall results show trade openness harms the economic growth of Eastern Africa. This finding contradicts the study of Abdillahi and Manini (2017) who found a significant positive impact of trade openness on economic growth. GFCF, FD, and FDI exhibit a positive impact on GDP per capita for Eastern Africa regions. These show that among other variables that GFCF and FD firmly promote economic growth at a $1 \%$ significance level. On the other hand, LAB, EXC, and CPI negatively impact GDP per capita. These findings suggest labor force, exchange rate depreciation, and consumer price index harms economic growth.

Similarly, the Southern Africa region in Table 2 shows trade openness has a mixed impact on economic growth. The overall results are similar to the study by (Moyo \& Khobai, 2018; Farahane \& Heshmati, 2020), as openness is detrimental to GDP per capita. Also, the results contrast Dava's (2012) positive effect of trade liberalization on growth. GFCF, EXC, FD, and CPI show a positive effect on GDP per capita but, CPI is insignificant on economic growth. In contrast, LAB and FDI indicate a negative and firmly statistically significant effect on GDP per capita.

\subsection{The Fixed Effect Results}

Table 3 for the whole sample shows the results of the enhanced model employing the FEM estimators, which tested for panel heterogeneities. The Hausman test is also used in the study to choose which of the two models to adopt. Because the validity of the REM is rejected by the results of this test, we will focus our investigation on the fixed-effects model and report the REM for our objective. The findings for Table 3 show that trade openness has a negative influence on Africa's growth. Precisely, OPEN1 and OPEN2 are statistically significant, 
M. Y. Bunje et al.

Table 3. Fixed and random effect results, dependent variable InGDPPC.

\begin{tabular}{|c|c|c|c|c|c|c|c|c|}
\hline \multirow{2}{*}{ Variables } & \multicolumn{4}{|c|}{ Fixed effect } & \multicolumn{4}{|c|}{ Random effect } \\
\hline & OPEN1 & OPEN2 & OPEN3 & OPEN4 & OPEN1 & OPEN2 & OPEN3 & OPEN4 \\
\hline \multirow{2}{*}{ OPEN' } & $-0.252^{\star * *}$ & $-0.366^{* * *}$ & -0.0343 & -0.0214 & $-0.241^{* * *}$ & $-0.371^{\star * *}$ & -0.010 & -0.006 \\
\hline & $(0.0335)$ & $(0.0309)$ & $(0.0252)$ & $(0.0157)$ & $(0.034)$ & $(0.031)$ & $(0.026)$ & $(0.016)$ \\
\hline \multirow{2}{*}{ InGFCF } & $0.0952^{* * *}$ & $0.141^{\star * \star}$ & 0.0388 & 0.0388 & $0.101^{\star * *}$ & $0.150^{* * *}$ & $0.0489^{\star}$ & $0.048^{*}$ \\
\hline & $(0.0249)$ & $(0.0243)$ & $(0.0245)$ & $(0.0245)$ & $(0.025)$ & $(0.024)$ & $(0.026)$ & $(0.026)$ \\
\hline \multirow{2}{*}{ InLAB } & $0.394^{\star * *}$ & $0.363^{* * *}$ & $0.426^{* * *}$ & $0.426^{* * *}$ & $-0.158^{\star * *}$ & $-0.160^{\star * *}$ & $-0.172^{\star * *}$ & $-0.172^{\star * *}$ \\
\hline & $(0.129)$ & $(0.124)$ & $(0.133)$ & $(0.133)$ & $(0.057)$ & $(0.059)$ & $(0.048)$ & $(0.048)$ \\
\hline \multirow{2}{*}{ InEXC } & $0.0194^{\star * *}$ & $0.0189^{* * *}$ & $0.0230^{* * *}$ & $0.0230^{* * *}$ & 0.0113 & $0.0115^{\star}$ & 0.012 & 0.012 \\
\hline & $(0.00693)$ & $(0.00664)$ & $(0.00715)$ & $(0.00715)$ & $(0.007)$ & $(0.006)$ & $(0.007)$ & $(0.007)$ \\
\hline \multirow{2}{*}{ InFD } & $-0.0452^{\star \star}$ & -0.0269 & $-0.0569^{\star * *}$ & $-0.0569^{* * *}$ & -0.0190 & -0.00282 & -0.0210 & -0.0210 \\
\hline & $(0.0194)$ & $(0.0187)$ & $(0.0199)$ & $(0.0199)$ & $(0.0197)$ & $(0.0189)$ & $(0.0206)$ & $(0.0206)$ \\
\hline \multirow{2}{*}{ InFDI } & $-0.0752^{\star * *}$ & $-0.0555^{\star * *}$ & $-0.0931^{\star * *}$ & $-0.0931^{* * *}$ & $-0.0854^{\star * *}$ & $-0.0635^{\star * *}$ & $-0.105^{\star * \star}$ & $-0.105^{\star \star \star}$ \\
\hline & $(0.0181)$ & $(0.0175)$ & $(0.0185)$ & $(0.0185)$ & $(0.0187)$ & $(0.0179)$ & $(0.0196)$ & $(0.0196)$ \\
\hline \multirow{2}{*}{ InCPI } & $-0.0950^{\star * *}$ & $-0.0804^{\star *}$ & $-0.0912^{\star *}$ & $-0.0912^{\star *}$ & $-0.0938^{\star *}$ & $-0.0798^{\star *}$ & $-0.0864^{\star *}$ & $-0.0864^{* *}$ \\
\hline & $(0.0361)$ & $(0.0346)$ & $(0.0372)$ & $(0.0372)$ & $(0.0374)$ & $(0.0356)$ & $(0.0396)$ & $(0.0396)$ \\
\hline \multirow{2}{*}{ Constant } & 2.821 & $3.262^{\star}$ & 1.602 & 1.489 & $11.07^{\star * *}$ & $11.12^{\star * *}$ & $10.48^{\star * *}$ & $10.44^{\star * *}$ \\
\hline & (1.958) & $(1.875)$ & $(2.024)$ & $(2.014)$ & $(0.916)$ & $(0.928)$ & $(0.777)$ & $(0.766)$ \\
\hline Yeardummies & Yes & Yes & Yes & Yes & Yes & Yes & Yes & Yes \\
\hline Observations & 988 & 988 & 988 & 988 & 988 & 988 & 988 & 988 \\
\hline $\mathrm{N}^{\circ}$ ofcountry & 52 & 52 & 52 & 52 & 52 & 52 & 52 & 52 \\
\hline R-squared & 0.782 & 0.799 & 0.769 & 0.769 & & & & \\
\hline F statistics & 269.33 & 293.04 & 179.55 & 179.55 & & & & \\
\hline BP LM test & & & & & 5494.76 & 6109.42 & 4018.32 & 4018.35 \\
\hline
\end{tabular}

Notes: ${ }^{* *},{ }^{* *}$, and ${ }^{*}$ indicate statistical significance at the $1 \%, 5 \%$, and $10 \%$ levels, respectively; $t$-statistics (in parentheses). Source: Authors' compilation

while OPEN3 and OPEN4 are not significant on economic growth. This demonstrates that a $1 \%$ rise in trade openness decreases Africa's GDP per capita by $(0.252 \%, 0.366 \%, 0.0343 \%$, and $0.0214 \%)$ for OPEN1, OPEN2, OPEN3, and OPEN4 respectively everything being equal. This result opposes related studies by Iyoha and Okim (2017) and Abendin and Duan (2021).

Also, we observe that the coefficients GFCF positively influence economic growth for FEM. Our results support previous findings by Iyoha and Okim (2017) and contrast Abendin and Duan (2021). LAB and EXC show a positive and statistically significant effect on GDP per capita on all measures of openness in the 
FEM model. This finding suggests that exchange rate fluctuations promote economic growth in Africa. This finding is similar to Alege and Osabuohien (2015) that show exports and imports are unresponsive to changes in the exchange rate. Table 3 shows that across the four trade openness measures, the anticipated coefficients for the parameters financial development, foreign direct investment, and the consumer price index all have an adverse influence on Africa's economic growth at a $1 \%$ significant level.

\subsection{The Dynamic System-GMM Results and Sensitivity Tests}

After correcting for potential factors omitted, endogeneity, and heteroscedasticity, Table 4 shows the results of the influence of trade openness on economic growth in Africa. In three measures, the trade openness coefficients are positive and substantial. As a result, the impact of trade openness on African economic growth appears to be uneven. At a 5\% significance level, these show that a $1 \%$ rise in trade, exports, and trade openness index improves GDP per capita by $0.0649 \%, 0.0733 \%$, and $0.0458 \%$, respectively. On the other hand, at a $1 \%$ significance level, a $1 \%$ rise in imports reduces GDP per capita by $0.0890 \%$ on average ceteris paribus. A study by Yusoff and Nulambeh (2016) found that imports have a negative influence on GDP per capita. As a prerequisite of old structural economic theory importations should be restricted until the domestic firms are found to be more competitive in the market. These findings show that the economies' unduly huge size could be both an advantage and a drawback when they are open. This finding is consistent with the full sample and Central Africa sub-region POLS model. Our results support related findings of Gabriel and David (2021) and Ulaşan (2015) which confirm that trade openness is not robust across different measures of openness. Our results contrast past studies by Jouini (2015) as his results were robust with alternative measures of openness.

At a $1 \%$ significance level, GFCF shows a positive and statistically significant link with economic growth. Our results are similar to the full sample POLS, the sub-regions of Southern Africa and the Eastern Africa countries. Our findings concord with the existing literature from studies by Gabriel and David (2021). On the other hand, LAB and FDI exhibit a negative and statistically significant economic growth impact across all the four openness measures estimated. These results are similar to the POLS estimators and the effect of FDI by Massell et al. (1972). Moreover, CPI and EXC exhibit negative and statistically insignificant economic effects in all measures of trade openness but for OPEN2 exchange rate is significant at a $5 \%$ level in Table 4 . The implication of CPI postulates that macroeconomic instability does not significantly spur growth in Africa. The finding on exchange rate viability is similar to those obtained by Dollar (1992). Financial development shows a positive impact on economic growth but is insignificant for OPEN3 and OPEN4.

To account for the accuracy of instrument variables (IVs), we execute the following tests and give the results: the accuracy of the additional instruments 
Table 4. System GMM results, dependent variable InGDPPC.

\begin{tabular}{|c|c|c|c|c|c|c|c|c|}
\hline \multirow{2}{*}{ Variables } & \multicolumn{4}{|c|}{ Main regression } & \multicolumn{4}{|c|}{ Robustness checks } \\
\hline & OPEN1 & OPEN2 & OPEN3 & OPEN4 & OPEN1 & OPEN2 & OPEN3 & OPEN4 \\
\hline \multirow{2}{*}{ L. InGDPPC } & $0.852^{\star \star \star}$ & $0.836^{* * *}$ & $0.883^{* * *}$ & $0.883^{\star * *}$ & $0.852^{* * *}$ & $0.836^{\star * *}$ & $0.883^{\star \star \star *}$ & $0.883^{\star \star *}$ \\
\hline & $(0.026)$ & $(0.034)$ & $(0.034)$ & $(0.034)$ & $(0.076)$ & $(0.097)$ & $(0.077)$ & $(0.077)$ \\
\hline \multirow{2}{*}{ OPEN' } & $0.064^{\star \star}$ & $-0.089^{* * *}$ & $0.0733^{\star *}$ & $0.0458^{\star \star}$ & 0.0649 & -0.0890 & 0.0733 & 0.0458 \\
\hline & $(0.026)$ & $(0.030)$ & $(0.0286)$ & $(0.017)$ & $(0.060)$ & $(0.080)$ & $(0.063)$ & $(0.039)$ \\
\hline \multirow{2}{*}{ InGFCF } & $0.106^{\star * *}$ & $0.151^{\star * *}$ & $0.088^{\star * *}$ & $0.088^{\star * *}$ & $0.106^{\star * *}$ & $0.151^{\star *}$ & $0.088^{\star * *}$ & $0.088^{* * *}$ \\
\hline & $(0.015)$ & $(0.024)$ & $(0.013)$ & $(0.013)$ & $(0.037)$ & $(0.061)$ & $(0.028)$ & $(0.028)$ \\
\hline \multirow{2}{*}{$\ln L A B$} & $-0.025^{\star * *}$ & $-0.046^{\star * *}$ & $-0.015^{\star}$ & $-0.015^{\star}$ & -0.025 & -0.046 & -0.015 & -0.015 \\
\hline & $(0.008)$ & $(0.0115)$ & $(0.007)$ & $(0.007)$ & $(0.0207)$ & $(0.037)$ & $(0.016)$ & $(0.016)$ \\
\hline \multirow{2}{*}{ InEXC } & -0.007 & $-0.0170^{\star *}$ & -0.005 & -0.005 & -0.007 & -0.017 & -0.005 & -0.005 \\
\hline & $(0.007)$ & $(0.007)$ & $(0.006)$ & $(0.006)$ & $(0.012)$ & $(0.015)$ & $(0.009)$ & $(0.009)$ \\
\hline \multirow{2}{*}{ InFD } & $0.0251^{\star}$ & $0.0422^{* * *}$ & 0.0119 & 0.0119 & 0.0251 & 0.0422 & 0.0119 & 0.0119 \\
\hline & $(0.0137)$ & $(0.013)$ & $(0.011)$ & $(0.011)$ & $(0.030)$ & $(0.042)$ & $(0.024)$ & $(0.024)$ \\
\hline \multirow{2}{*}{ InFDI } & $-0.044^{* * *}$ & $-0.018^{\star}$ & $-0.036^{* * *}$ & $-0.036^{* * *}$ & $-0.044^{*}$ & -0.018 & $-0.036^{\star *}$ & $-0.036^{\star \star}$ \\
\hline & $(0.007)$ & $(0.009)$ & $(0.006)$ & $(0.006)$ & $(0.024)$ & $(0.022)$ & $(0.018)$ & $(0.018)$ \\
\hline \multirow{2}{*}{ InCPI } & -0.0281 & -0.0350 & -0.0176 & -0.0176 & -0.0281 & -0.0350 & -0.0176 & -0.0176 \\
\hline & $(0.053)$ & $(0.045)$ & $(0.047)$ & $(0.047)$ & $(0.101)$ & $(0.098)$ & $(0.0698)$ & $(0.069)$ \\
\hline \multirow{2}{*}{ Constant } & $1.147^{\star * *}$ & $1.748^{* * *}$ & $0.613^{*}$ & $0.854^{\star *}$ & 1.147 & 1.748 & 0.613 & 0.854 \\
\hline & $(0.353)$ & $(0.473)$ & $(0.327)$ & $(0.387)$ & $(0.802)$ & $(1.243)$ & $(0.596)$ & $(0.756)$ \\
\hline Year dummies & Yes & Yes & Yes & Yes & Yes & Yes & Yes & Yes \\
\hline Observations & 936 & 936 & 936 & 936 & 936 & 936 & 936 & 936 \\
\hline Number of Country & 52 & 52 & 52 & 52 & 52 & 52 & 52 & 52 \\
\hline Instruments/Groups & $45 / 52$ & $45 / 52$ & $45 / 52$ & $45 / 52$ & $45 / 52$ & $45 / 52$ & $45 / 52$ & $45 / 52$ \\
\hline $\operatorname{AR}(1)$ & 0.004 & 0.004 & 0.004 & 0.004 & 0.005 & 0.006 & 0.005 & 0.005 \\
\hline $\operatorname{AR}(2)$ & 0.851 & 0.958 & 0.823 & 0.823 & 0.851 & 0.959 & 0.823 & 0.823 \\
\hline Sargan test & 0.120 & 0.008 & 0.109 & 0.109 & 0.120 & 0.008 & 0.109 & 0.109 \\
\hline Hansen test & 0.119 & 0.113 & 0.169 & 0.169 & 0.119 & 0.113 & 0.169 & 0.169 \\
\hline
\end{tabular}

Notes: ${ }^{* *},{ }^{* *}$, and ${ }^{\star}$ indicate statistical significance at the $1 \%, 5 \%$, and $10 \%$ levels, respectively; $t$-statistics (in parentheses). Source: Authors' compilation.

associated with the sys-GMM estimator is demonstrated by the Hansen-Sargan test for over-identification and the accompanying $p$-values for all IVs of the additional orthogonality requirements for the level equation. Table 4 indicates that the econometric specification tests with statistical significance validate the soundness of these IVs and do not reject the hypothesis at Roodman's (2009) recom- 
mended 0.5 or 0.10 values. Furthermore, the reliability of the results obtained using the dynamic model estimator is determined by the validity of the instruments. The AR (1) test fails, but the AR (2) test succeeds, indicating that the assumption that the residuals are not serially linked at the second-order level. As a result, the findings of the augmented sys-GMM estimation can be used to make decisions.

We conducted several robustness tests; firstly, we use four alternative measures of trade openness in four different models of estimation. Results using these measures and models show that both the fixed effects and random effects coefficients of openness do not spur economic growth. However, the POLS and system GMM indicated trade openness has a mixed impact on GDP per capita for African countries. The overall result posits that trade openness is not robust for Africa economies. Secondly, considering the system GMM as the target regression model, we reported system GMM robustness check regression estimation in Table 4. The results produce the same output but insignificant effect on GDP per capita. These findings confirm that trade openness is not robustly associated with economic growth.

\subsection{Multicollinearity Test}

Since our models have several variables and are expressed in logarithmic form, it's crucial to test for multi-collinearity. The danger of multi-collinearity in the logarithmic specs of the models was assessed using the Variance Inflation Factor (VIF). The estimate of the parameters becomes wrong when numerous variables are employed, and the standard errors for the coefficients become greatly exaggerated. Table 5 shows the results of the VIF test for multicollinearity, which show that the components in the models are not highly related. As a result, the coefficient estimation and model standard errors are accurate estimations.

Table 5. Multicollinearity test results, dependent variable InGDPPC.

\begin{tabular}{ccccccccc}
\hline \multirow{2}{*}{ Variables } & \multicolumn{2}{c}{ OPEN1 } & \multicolumn{2}{c}{ OPEN2 } & \multicolumn{2}{c}{ OPEN3 } & \multicolumn{2}{c}{ OPEN4 } \\
\cline { 2 - 9 } & VIF & 1/VIF & VIF & 1/VIF & VIF & $1 /$ VIF & VIF & $1 /$ VIF \\
\hline OPEN' & 1.73 & 0.577497 & 1.81 & 0.551548 & 1.30 & 0.768143 & 1.30 & 0.768139 \\
InLAB & 1.35 & 0.740818 & 1.40 & 0.713759 & 1.14 & 0.875889 & In1.14 & 0.875888 \\
InFD & 1.29 & 0.776000 & 1.32 & 0.759894 & 1.28 & 0.781971 & 1.28 & 0.781971 \\
InEXC & 1.28 & 0.781451 & 1.24 & 0.804427 & 1.27 & 0.789639 & 1.27 & 0.789638 \\
InGFCF & 1.28 & 0.782276 & 1.21 & 0.824106 & 1.26 & 0.794490 & 1.26 & 0.794489 \\
InFDI & 1.19 & 0.842609 & 1.25 & 0.802658 & 1.15 & 0.872585 & 1.15 & 0.872585 \\
InCPI & 1.05 & 0.955447 & 1.05 & 0.954831 & 1.05 & 0.954151 & 1.05 & 0.954151 \\
Mean VIF & 1.31 & & 1.33 & & 1.21 & & 1.21 & \\
\hline
\end{tabular}

Note: when the VIF of a variable is more than 5, we examine the presence of multicollinearity in our logarithmic specifications. Source: Authors' Compilation. 


\section{Conclusion and Implication}

Given that both empirical and theoretical literature on the influence of trade openness on GDP shows a mixed impact. By examining the relationship between trade openness and GDP per capita, by recognizing that short-time-horizons in obtaining high growth rates is a key policy goal. This study fills a gap in the literature. We employ three generally used measures of trade openness and a composite trade openness index to see the influence on GDP per capita in African nations, starting with the assumption that openness to trade cannot be properly represented by a single measure of trade openness. Our empirical approach is based on annual data from 2000 to 2018 for a balanced panel of 52 African countries. Because most explanatory variables are likely to be jointly endogenous with GDP, we use 4 estimating models: pooled ordinary least squares, random and fixed effects, and the generalized methods of moment's estimations for investigation. We offer some persuasive and comprehensive studies that show that Africa's openness has a statistically significant effect on economic growth. Our analysis indicates that trade openness has different effects on growth throughout the four estimation models and sub-regions.

The POLS model shows that trade openness (trade, exports, and trade openness index) has considerable beneficial effects on Africa's economic growth, whereas imports have a significant negative effect. Trade has negative effects on economic growth, according to the fixed effects estimations, although only trade and imports models of openness are significant on economic growth. These findings back up the conclusions of the previous study by Adeleye and Eboagu, 2019; Abendin and Duan, 2021; and Yusoff and Nulambeh (2016). The POLS model suggests that trade openness has a mixed influence on economic growth, and the sys-GMM estimations produced comparable results. According to the findings, the direct impact of various openness measures on economic growth differed across the five sub-regions. Across the five sub-regions, trade openness has a mixed impact on economic growth. Besides, Northern Africa's results are robust on economic growth. Among trade openness variables other determinants of economic growth such as gross fixed capital formation, labor force, exchange rate, financial development, foreign direct investment, and consumer price index were included to examine its influence on GDP per capita. Their results show varying outcomes across the four models of estimation.

Furthermore, this study concludes that the effects of trade openness influence Africa's economic growth. The study also finds that the estimating methodologies have a different openness-growth link. Finally, sub-regions have a diverse openness-growth relationship. As a result, the report recommends that African governments implement trade policies that increase exports through manufacturing products while reducing imports for non-capital goods to generate a trade surplus as, increased imports to trade put Africa's prosperity in jeopardy. In this context, we advocate that governments pursue policies to support increasing trade by encouraging export expansion, limiting imports of consumable prod- 
ucts, and fostering regional growth to reap the full economic benefits of international trade.

Moreover, as the Western countries and their multinational corporations dominate and exploit poorer countries' economies, developing countries particularly African nations need to strategize and break the dependency trap. As proposed by the old structural economists, import substitution strategies should be prioritized, with developing economies closed and protected until their modern industries can compete in global markets with advanced industrialized countries. As a strategy to bring in foreign currency through export revenues, we suggested trade openness and export promotion. This is also in line with the belief that outward-oriented development methods are more beneficial in the long run than inward-looking ones. The view that such a plan would raise demand for unskilled labor and thus unskilled pay strengthened this perspective even more.

Specifically, based on sub-regional results and the trade flows (imports and exports), the regions possess comparative advantage (that is, export what the rest of the world needs and are slowly upgrading its industries step by step at a pace consistent with the change in its endowment structure to make its economy competitive exports in the sub-regions). On the other hand, imports apart from the Northern Africa sub-region should be restricted to boost domestic production of consumable goods. The governments should look into policies initiatives on maintaining macroeconomic stability, keeping high rates of saving and investment, using markets to allocate resources, and having committed, credible, and capable governments. Also, policymakers and governing authorities should adapt marketing goods through E-trade platforms to maximize continuous sustainable growth.

\section{Acknowledgements}

This paper was funded by the National Social Science Fund (20FGLB071); General research project of Humanities and Social Sciences in Colleges and universities of Henan Province (2021-ZZJH-370).

\section{Conflicts of Interest}

The authors declare no conflicts of interest regarding the publication of this paper.

\section{References}

Abdillahi, U. A., \& Manini, M. M. (2017). Impact of Trade Openness on Economic Growth in Kenya. International Journal of Economics, Commerce and Management, 5, 109-137.

Abendin, S., \& Duan, P. (2021). International Trade and Economic Growth in Africa: The Role of the Digital Economy. Cogent Economics \& Finance, 9, Article ID: 1911767. https://doi.org/10.1080/23322039.2021.1911767

Adeleye, N., \& Chiamaka, E. (2019). Evaluation of ICT Development and Economic Growth in Africa. NETNOMICS: Economic Research and Electronic Networking, 20, 31-53. 
https://doi.org/10.1007/s11066-019-09131-6

Adhikary, B. K. (2011). FDI, Trade Openness, Capital Formation, and Economic Growth in Bangladesh: A Linkage Analysis. International Journal of Business and Management, 6, 16-28. https://ccsenet.org/journal/index.php/ijbm/article/view/7472 https://doi.org/10.5539/ijbm.v6n1p16

Adjasi, C. K., Abor, J., Osei, K. A., \& Nyavor-Foli, E. E. (2012). FDI and Economic Activity in Africa: The Role of Local Financial Markets. Thunderbird International Business Review, 54, 429-439. https://doi.org/10.1002/tie.21474

Aghion, P., \& Howitt, P. (2005). Growth with Quality-Improving Innovations: An Integrated Framework. In Handbook of Economic Growth, (Vol. 1, pp. 67-110). Elsevier. https://doi.org/10.1016/S1574-0684(05)01002-6

Alege, P. O., \& Osabuohien, E. S. (2015). Trade-Exchange Rate Nexus in Sub-Saharan African Countries: Evidence from Panel Cointegration Analysis. Foreign Trade Review, 50, 151-167. https://doi.org/10.1177/0015732515589440

Alfaro, L., Chanda, A., Kalemli-Ozcan, S., \& Sayek, S. (2010). Does Foreign Direct Investment Promote Growth? Exploring the Role of Financial Markets on Linkages. Journal of Development Economics, 91, 242-256.

https://doi.org/10.1016/j.jdeveco.2009.09.004

Amna Intisar, R., Yaseen, M. R., Kousar, R., Usman, M., \& Makhdum, M. S. A. (2020). Impact of Trade Openness and Human Capital on Economic Growth: A Comparative Investigation of Asian Countries. Sustainability, 12, Article 2930. https://doi.org/10.3390/su12072930

Arellano, M., \& Bover, O. (1995). Another Look at the Instrumental Variable Estimation of Error Components Models. Journal of Econometrics, 68, 29-51. https://doi.org/10.1016/0304-4076(94)01642-D

Asiedu, M. K. (2013). Trade Liberalization and Growth: The Ghanaian Experience. Journal of Economic and Sustainable Development, 4, 124-135.

https://www.scirp.org/reference/ReferencesPapers.aspx?ReferenceID=2095627

Beck, T. (2002). Financial Development and International Trade: Is There a Link? Journal of international Economics, 57, 107-131. https://doi.org/10.1016/S0022-1996(01)00131-3

Beugelsdijk, S., Smeets, R., \& Zwinkels, R. (2008). The Impact of Horizontal and Vertical FDI on Host's Country Economic Growth. International Business Review, 17, 452-472. https://doi.org/10.1016/j.ibusrev.2008.02.004

Blundell, R., \& Bond, S. (1998). Initial Conditions and Moment Restrictions in Dynamic Panel Data Models. Journal of Econometrics, 87, 115-143. https://doi.org/10.1016/S0304-4076(98)00009-8

Bowsher, C. G. (2002). On Testing Overidentifying Restrictions in Dynamic Panel Data Models. Economics Letters, 77, 211-220. https://doi.org/10.1016/S0165-1765(02)00130-1

Çevik, E. İ., Atukeren, E., \& Korkmaz, T. (2019). Trade Openness and Economic Growth in Turkey: A Rolling Frequency Domain Analysis. Economies, 7, Article 41. https://doi.org/10.3390/economies7020041

Chang, C. C., \& Mendy, M. (2012). Economic Growth and Openness in Africa: What Is the Empirical Relationship? Applied Economics Letters, 19, 1903-1907. https://doi.org/10.1080/13504851.2012.676728

Cobb, C. W., \& Douglas, P. H. (1928). A Theory of Production. The American Economic Review, 18, 139-165. 
Dava, E. (2012). Trade Liberalization and Economic Growth in the SADC: A Difference in Difference Analysis. IESE Conference Paper (No. 8).

Doan, H. Q. (2019). Trade, Institutional Quality and Income: Empirical Evidence for Sub-Saharan Africa. Economies, 7, Article 48. https://doi.org/10.3390/economies7020048

Dollar, D. (1992). Outward-Oriented Developing Economies Really Do Grow More Rapidly: Evidence from 95 LDCs, 1976-1985. Economic Development and Cultural Change, 40, 523-544. https://doi.org/10.1086/451959

Dreher, A. (2006). Does Globalization Affect Growth? Evidence from a New Index of Globalization. Applied Economics, 38, 1091-1110. https://doi.org/10.1080/00036840500392078

Duodu, E., \& Baidoo, S. T. (2020). How Does Quality of Institutions Affect the Impact of Trade Openness on Economic Growth of Ghana? Cogent Economics \& Finance, 8, Article ID: 1812258. https://doi.org/10.1080/23322039.2020.1812258

Farahane, M., \& Heshmati, A. (2020). Trade and Economic Growth: Theories and Evidence from the Southern African Development Community. IZA Discussion Paper No. 13679. https://doi.org/10.2139/ssrn.3691392

Frankel, J. A., \& Romer, D. (1999). Does Trade Cause Growth? American Economic Review, 83, 379-399. https://doi.org/10.1257/aer.89.3.379

Gabriel, A. A., \& David, A. O. (2021). Effect of Trade Openness and Financial Openness on Economic Growth in Sub-Saharan African Countries. African Journal of Economic Review, 9, 109-130.

Grossman, G. M., \& Helpman, E. (2015). Globalization and Growth. American Economic Review, 105, 100-104. https://doi.org/10.1257/aer.p20151068

Hicks, J. (1965). Capital and Growth. Oxford University Press.

Huang, L. C., \& Chang, S. H. (2014). Revisit the Nexus of Trade Openness and GDP Growth: Does the Financial System Matter? The Journal of International Trade \& Economic Development, 23, 1038-1058. https://doi.org/10.1080/09638199.2013.830638

Huchet-Bourdon, M., Le Mouël, C., \& Vijil, M. (2018). The Relationship between Trade Openness and Economic Growth: Some New Insights on the Openness Measurement Issue. The World Economy, 41, 59-76. https://doi.org/10.1111/twec.12586

Hye, Q. M. A., \& Lau, W. Y. (2015). Trade Openness and Economic Growth: Empirical Evidence from India. Journal of Business Economics and Management, 16, 188-205. https://doi.org/10.3846/16111699.2012.720587

Hye, Q. M. A., Wizarat, S., \& Lau, W. Y. (2016). The Impact of Trade Openness on Economic Growth in China: An Empirical Analysis. The Journal of Asian Finance, Economics, and Business, 3, 27-37. https://doi.org/10.13106/jafeb.2016.vol3.no3.27

Ijirshar, V. U. (2019). Impact of Trade Openness on Economic Growth among ECOWAS Countries: 1975-2017. CBN Journal of Applied Statistics (JAS), 10, Article 4. https://www.cbn.gov.ng/Out/2019/STD/75\%20-\%2096_Ijirshar.pdf

Iyoha, M., \& Okim, A. (2017). The Impact of Trade on Economic Growth in ECOWAS Countries: Evidence from Panel Data. CBN Journal of Applied Statistics, 8, 23-49. http://hdl.handle.net/10419/191700

Jolliffe, I. T., \& Cadima, J. (2016). Principal Component Analysis: A Review and Recent Developments. Philosophical Transactions of the Royal Society A: Mathematical, Physical and Engineering Sciences, 374, Article ID: 20150202.

Jouini, J. (2015). Linkage between International Trade and Economic Growth in GCC 
Countries: Empirical Evidence from PMG Estimation Approach. The Journal of International Trade \& Economic Development, 24, 341-372. https://doi.org/10.1080/09638199.2014.904394

Keho, Y. (2017). The Impact of Trade Openness on Economic Growth: The Case of Cote d'Ivoire. Cogent Economics \& Finance, 5, Article ID: 1332820. https://doi.org/10.1080/23322039.2017.1332820

Kim, D. H. (2011). Trade, Growth and Income. The Journal of International Trade \& Economic Development, 20, 677-709. https://doi.org/10.1080/09638199.2011.538966

Kim, D. H., Lin, S. C., \& Suen, Y. B. (2016). Trade, Growth and Growth Volatility: New Panel Evidence. International Review of Economics \& Finance, 45, 384-399. https://doi.org/10.1016/j.iref.2016.07.006

Kuznets, S., \& Murphy, J. T. (1966). Modern Economic Growth: Rate, Structure, and Spread (Vol. 2). Yale University Press.

Lam, T. (2015). A Review of Modern International Trade Theories. American Journal of Economics, Finance and Management, 1, 604-614.

Le Goff, M., \& Singh, R. J. (2014). Does Trade Reduce Poverty? A View from Africa. Journal of African Trade, 1, 5-14. https://doi.org/10.1016/j.joat.2014.06.001

Levine, R., \& Renelt, D. (1992). A Sensitivity Analysis of Cross-Country Growth Regressions. The American Economic Review, 82, 942-963.

Lin, J. Y. (2011). New Structural Economics: A Framework for Rethinking Development. The World Bank Research Observer, 26, 193-221. https://doi.org/10.1093/wbro/lkr007

Lin, J. Y. (2012). New Structural Economics: A Framework for Rethinking Development and Policy (pp. 371). World Bank. https://doi.org/10.1596/978-0-8213-8955-3

Lin, J. Y., \& Monga, C. (2010). The Growth Report and New Structural Economics. World Bank Policy Research Working Paper (5336).

Madsen, J. B. (2009). Trade Barriers, Openness, and Economic Growth. Southern Economic Journal, 76, 397-418. https://doi.org/10.4284/sej.2009.76.2.397

Malefane, M. R., \& Odhiambo, N. M. (2018). Impact of Trade Openness on Economic Growth: Empirical Evidence from South Africa. Economia Internazionale/International Economics, 71, 387-416.

Manwa, F., \& Wijeweera, A. (2016). Trade Liberalisation and Economic Growth Link: The Case of Southern African Custom Union Countries. Economic Analysis and Policy, 51, 12-21. https://doi.org/10.1016/j.eap.2016.05.001

Manwa, F., Wijeweera, A., \& Kortt, M. A. (2019). Trade and Growth in SACU Countries: A Panel Data Analysis. Economic Analysis and Policy, 63, 107-118. https://doi.org/10.1016/j.eap.2019.05.003

Massell, B. F., Pearson, S. R., \& Fitch, J. B. (1972). Foreign Exchange and Economic Development: An Empirical Study of Selected Latin American Countries. The Review of Economics and Statistics, 54, 208-212. https://doi.org/10.2307/1926287

Mbate, M. (2015). Can Africa Diversify Its Exports? Lessons from Ethiopia. Development, 58, 614-619. https://doi.org/10.1057/s41301-016-0048-7

Menyah, K., Nazlioglu, S., \& Wolde-Rufael, Y. (2014). Financial Development, Trade Openness and Economic Growth in African Countries: New Insights from a Panel Causality Approach. Economic Modelling, 37, 386-394.

https://doi.org/10.1016/j.econmod.2013.11.044

Moyo, C., \& Khobai, H. (2018). Trade Openness and Economic Growth in SADC Countries. MPRA Paper No. 84254. 
Ngimanang, A. (2020). Examining the Finance-Growth Nexus in Cameroon Using Cointegration Approach. American Journal of Economics, 4, 1-17. https://doi.org/10.47672/aje.592

Pritchett, L. (2006). The Quest Continues. Finance \& Development, 43, 18-22.

Ramsey, F. P. (1928). A Mathematical Theory of Saving. The Economic Journal, 38, 543-559. https://doi.org/10.2307/2224098

Ramzan, M., Sheng, B., Shahbaz, M., Song, J., \& Jiao, Z. (2019). Impact of Trade Openness on GDP Growth: Does TFP Matter? The Journal of International Trade \& Economic Development, 28, 960-995. https://doi.org/10.1080/09638199.2019.1616805

Rao, B. B., \& Cooray, A. (2012). How Useful Is Growth Literature for Policies in the Developing Countries? Applied Economics, 44, 671-681. https://doi.org/10.1080/00036846.2010.517188

Rodriguez, F., \& Rodrik, D. (2000). Trade Policy and Economic Growth: A Skeptic's Guide to the Cross-National Evidence. NBER Macroeconomics Annual, 15, 261-325. https://doi.org/10.1086/654419

Rodrik, D. (1992). The Limits of Trade Policy Reform in Developing Countries. Journal of Economic Perspectives, 6, 87-105. https://doi.org/10.1257/jep.6.1.87

Roodman, D. (2009). A Note on the Theme of Too Many Instruments. Oxford Bulletin of Economics and Statistics, 71, 135-158. https://doi.org/10.1111/j.1468-0084.2008.00542.x

Schumpeter, J. (1934). The Theory of Economic Development. Harvard University Press.

Sghaier, I. M. (2020). Does Financial Development Affect the Economic Growth Gains from Trade Openness? Economic Alternatives, University of National and World Economy, Sofia, pp. 666-682. https://doi.org/10.37075/EA.2020.4.10

Solow, R. M. (1956). A Contribution to the Theory of Economic Growth. The Quarterly Journal of Economics, 70, 65-94. https://doi.org/10.2307/1884513

Stiglitz, J. E. (2004). Capital-Market Liberalization, Globalization, and the IMF. Oxford Review of Economic Policy, 20, 57-71. https://doi.org/10.1093/oxrep/grh004

Tinta, A. A., Sarpong, D. B., Ouedraogo, I. M., Al Hassan, R., Mensah-Bonsu, A., \& Ebo Onumah, E. (2018). The Effect of Integration, Global Value Chains and International Trade on Economic Growth and Food Security in ECOWAS. Cogent Food \& Agriculture, 4, Article ID: 1465327. https://doi.org/10.1080/23311932.2018.1465327

Trejos, S., \& Barboza, G. (2015). Dynamic Estimation of the Relationship between Trade Openness and Output Growth in Asia. Journal of Asian Economics, 36, 110-125. https://doi.org/10.1016/j.asieco.2014.10.001

Ulaşan, B. (2012). Openness to International Trade and Economic Growth: A Cross-Country Empirical Investigation. Economics Discussion Papers No. 2012-25.

http://hdl.handle.net/10419/58224

https://doi.org/10.2139/ssrn.2087930

Ulaşan, B. (2015). Trade Openness and Economic Growth: Panel Evidence. Applied Economics Letters, 22, 163-167. https://doi.org/10.1080/13504851.2014.931914

UNCTAD (2016). The Least Developed Countries Report 2016: The Path to Graduation and Beyond: Making the Most of the Process. In United Nations Conference on Trade and Development. UNCTAD/LDC/2016/Corr. 1.

https://unctad.org/system/files/official-document/ldc2016_en.pdf

UNIDO and UNCTAD (2011). Fostering Industrial Development in Africa in the New Global Environment. The Economic Development in Africa Report. 
https://unctad.org/system/files/official-document/aldcafrica2011_en.pdf

Wang, M., \& Wong, M. S. (2011). FDI, Education, and Economic Growth: Quality Matters. Atlantic Economic Journal, 39, 103-115. https://doi.org/10.1007/s11293-011-9268-0

Were, M. (2015). Differential Effects of Trade on Economic Growth and Investment: A Cross-Country Empirical Investigation. Journal of African Trade, 2, 71-85. https://doi.org/10.1016/j.joat.2015.08.002

Yanikkaya, H. (2003). Trade Openness and Economic Growth: A Cross-Country Empirical Investigation. Journal of Development Economics, 72, 57-89. https://doi.org/10.1016/S0304-3878(03)00068-3

Yusoff, M. B., \& Nulambeh, N. A. (2016). Exports, Imports, Exchange rates, Gross Domestic Investment and Growth: Empirical Evidence from Cameroon. IIARD International Journal of Economics and Business Management, 2, 18-32.

Zahonogo, P. (2016). Trade and Economic Growth in Developing Countries: Evidence from Sub-Saharan Africa. Journal of African Trade, 3, 41-56.

https://doi.org/10.1016/j.joat.2017.02.001 


\section{Appendix}

Table A1. List of sample countries.

\begin{tabular}{|c|c|c|c|c|}
\hline $\begin{array}{c}\text { Northern Africa } \\
\text { Nations }\end{array}$ & $\begin{array}{c}\text { Western Africa } \\
\text { Nations }\end{array}$ & $\begin{array}{l}\text { Central Africa } \\
\text { Nations }\end{array}$ & $\begin{array}{c}\text { Eastern Africa } \\
\text { Nations }\end{array}$ & $\begin{array}{c}\text { Southern Africa } \\
\text { Nations }\end{array}$ \\
\hline Algeria & Benin & Cameroon & Mauritius & Angola \\
\hline Egypt & Burkina Faso & Central Africa Republic & Burundi & Botswana \\
\hline Libya & Cabo Verde & Chad & Comoros & Eswatini \\
\hline Mauritania & Cote d'Ivoire & Congo Democratic & Djibouti & Lesotho \\
\hline Morocco & The Gambia & Congo DR & Eritrea & Malawi \\
\hline Sudan & Ghana & Equatorial Guinea & Ethiopia & Mozambique \\
\hline \multirow[t]{9}{*}{ Tunisia } & Guinea & Gabon & Kenya & Namibia \\
\hline & Guinea-Bissau & Sao Tome and Principe & Madagascar & South Africa \\
\hline & Liberia & & Rwanda & Zambia \\
\hline & Mali & & Tanzania & Zimbabwe \\
\hline & Niger & & Uganda & \\
\hline & Nigeria & & Seychelles & \\
\hline & Senegal & & & \\
\hline & Sierra Leone & & & \\
\hline & Togo & & & \\
\hline
\end{tabular}

Source: Authors' compilation.

Table A2. Variables description and data source.

\begin{tabular}{|c|c|c|}
\hline Variables & Description & $\begin{array}{c}\text { Data } \\
\text { source }\end{array}$ \\
\hline Economic Growth & $\begin{array}{l}\text { The quantity of the gross national product of all individual producers } \\
\text { in the country is quantified as GDP per capita (current US Dollars). }\end{array}$ & WDI \\
\hline Trade & $\begin{array}{l}\text { The degree to which a country allows international trade. It's computed } \\
\text { by dividing the total sum of exports and imports by GDP. }\end{array}$ & WDI \\
\hline Imports & $\begin{array}{l}\text { Imports are the total value of all products and services acquired from } \\
\text { outside the country. }\end{array}$ & WDI \\
\hline Exports & $\begin{array}{l}\text { Exports are the total value of all commodities and other market services } \\
\text { transferred to other countries. }\end{array}$ & WDI \\
\hline Gross fixed capital formation & $\begin{array}{l}\text { The costs of additions to all the economy's fixed assets are known as gross } \\
\text { fixed capital formation (previously gross domestic fixed investment). }\end{array}$ & WDI \\
\hline Labor force & $\begin{array}{l}\text { It consists of people aged } 15 \text { and up who provide labor to generate goods } \\
\text { and services for a set length of time. }\end{array}$ & WDI \\
\hline Exchange rate & $\begin{array}{l}\text { It refers to the rate set by national authorities or the rate set in a legally } \\
\text { regulated exchange market. }\end{array}$ & WDI \\
\hline
\end{tabular}


M. Y. Bunje et al.

\section{Continued}

Financial development

Foreign direct investment

Consumer price index
Domestic credit supplied by banks to the private sector refers to financial resources provided by financial firms to the private sector.

Foreign direct investment refers to a country's willingness to accept foreign capital into its economy.

The consumer price index (CPI) measures the annual percentage change in the cost of acquiring a basket of goods and services for the average consumer, which can be fixed or altered at regular intervals, such as annually.
WDI

WDI

WDI

Source: Authors' compilation.

Table A3. Summary statistics of all variables.

\begin{tabular}{cccccc}
\hline Variables & Obs. & Mean & Std. Dev. & Min & Max \\
\hline GDPPC & 988 & 2203.834 & 3083.916 & 111.9272 & $22,942.58$ \\
OPEN1 & 988 & 75.56986 & 41.10873 & 17.92676 & 347.9965 \\
OPEN2 & 988 & 43.08723 & 25.25473 & 10.0145 & 236.391 \\
OPEN3 & 988 & 32.48264 & 20.98673 & 4.428757 & 158.3742 \\
GFCF & 988 & 22.06761 & 9.101254 & 1.09681 & 79.46179 \\
LAB & 988 & $7,238,699$ & $9,918,870$ & $35,004.8$ & $6.05 \mathrm{e}+07$ \\
EXC & 988 & $6,805,240$ & $2.14 \mathrm{e}+08$ & 0.0024545 & $6.72 \mathrm{e}+09$ \\
FD & 988 & 19.75189 & 17.90671 & 0.4025806 & 106.2603 \\
FDI & 988 & 4.580687 & 8.103755 & -6.369877 & 103.3374 \\
CPI & 988 & 8.428137 & 25.03038 & -72.7 & 513.9068 \\
\hline
\end{tabular}

Source: Authors' compilation. 